\title{
Evaluation of radionuclide contamination of soil, coal ash and zeolitic materials from Figueira Thermoelectric Power
}

\section{Plant}

\author{
Fungaro $^{a}$ D. A., Silva ${ }^{a}$ P. S. C., Campello ${ }^{a}$ F. A., Miranda ${ }^{a}$ C. S., Izidoro ${ }^{a}$ J. C. \\ ${ }^{a}$ Instituto de Pesquisas Energéticas e Nucleares (IPEN/CNEN-SP), 05508-000, São Paulo, SP, Brazil
}

dfungaro@ipen.br

\begin{abstract}
The feed pulverized coal used at Figueira thermoelectric power plant (FTPP) presents a significant amount of uranium concentration and the potential radiological impact pathways into the surrounding environments should be monitored frequently. Neutron activation analysis was used to determine ${ }^{238} \mathrm{U}$ and ${ }^{232} \mathrm{Th}$, and gamma-ray spectrometry was used to determine ${ }^{226} \mathrm{Ra},{ }^{228} \mathrm{Ra},{ }^{210} \mathrm{~Pb}$ and ${ }^{40} \mathrm{~K}$ contents present in coal, different types of coal ashes, their synthesized zeolites and two different soil samples collected in the vicinity of FTPP as well as, radiological indices to determine possible health effects due to radiation exposition. The natural radionuclide concentrations in pulverized coal were $216 \mathrm{~Bq} \mathrm{~kg}^{-1}$ for ${ }^{238} \mathrm{U}, 180 \mathrm{~Bq} \mathrm{~kg}{ }^{-1}$ for ${ }^{226} \mathrm{Ra}, 27 \mathrm{~Bq} \mathrm{~kg}{ }^{-1}$ for ${ }^{228} \mathrm{Ra}, 28 \mathrm{~Bq} \mathrm{~kg}^{-1}$ for ${ }^{232} \mathrm{Th}$ and $192 \mathrm{~Bq} \mathrm{~kg}^{-1}$ for ${ }^{40} \mathrm{~K}$. The ashes fraction presented concentrations ranging from 683.5 to $1479 \mathrm{~Bq} \mathrm{~kg}^{-1}$ for ${ }^{238} \mathrm{U}$, from 484 to $1086 \mathrm{~Bq} \mathrm{~kg}^{-1}$ for ${ }^{226} \mathrm{Ra}$, from 291 to $1891 \mathrm{~Bq} \mathrm{~kg}{ }^{-1}$ for ${ }^{210} \mathrm{~Pb}$, from 67 to $111 \mathrm{~Bq} \mathrm{~kg}{ }^{-1}$ for ${ }^{228} \mathrm{Ra}$, from 80 to $87 \mathrm{~Bq} \mathrm{~kg}^{-1}$ for ${ }^{232} \mathrm{Th}$ and from 489 to $718 \mathrm{~Bq} \mathrm{~kg}^{-1}$ for ${ }^{40} \mathrm{~K}$. Similar ranges were observed for the different zeolitic products. The activity concentration of ${ }^{238} \mathrm{U}$ was higher than worldwide average concentration for all samples. The concentration of the uranium series found in the ashes was lower than the values observed in similar studies carried out 10 years ago and under the limit adopted by the Brazilian guideline (CNEN-NN-4.01). The radiological indices indicated that the environmental disposal of fly ashes may represent a risk for public health, therefore, the resulting data can be used for systematic studies on radiological implication due to the release of TENORM caused by coal-fired power plant.
\end{abstract}




\section{INTRODUCTION}

Coal, like most materials found in nature, contains trace quantities of the naturally occurring primordial radionuclides arising from the $\mathrm{U}$ and Th series and ${ }^{40} \mathrm{~K}$. Although the concentration of these long-lived radionuclides is usually low, some types of coal contain considerably higher amounts of natural radionuclides [1].

The combustion of coal leads to an increase of the natural radionuclides and non-combustible elements with enrichments factor in the ashes of 5-10 times [2]. The increase in specific activities of naturally occurring radionuclides in coal combustion residuals (CCRs) compared to the one of the original coals depends primarily on its inorganic fraction, i.e., the ash content.

This release of natural radioactive elements into the environment can cause its redistribution into surface soil, particularly in the vicinity of TENORM (Technologically Enhanced Naturally Occurring Radioactive Materials) industries, such as coal-fired power plants, modifying ambient radiation fields and population exposures. Since natural radionuclides are the main source of radiation exposure, the contribution coming from these TENORM activities may pose a threat to population health.

The coal used in Brazilian coal-fired power plants is pulverized and burned inside a boiler, producing bottom ash (15-20\%), which remains inside the boiler bottom, and fly ash (80-85\%) that is suspended in the flue gas together with vapors of volatile elements. The natural radionuclides are distributed among these fractions [3].

Previously, chemical-physical properties and leaching characteristics of Brazilian coal ashes have been investigated [4] and few studies showed the radioactivity concentration of coal and its combustion residues $[1,3]$.

Brazilian coals are richer in ash (content of 20-50 wt.\%) and poorer in carbon when compared to worldwide coal and coal ash disposal is a serious environmental concern. Only $30 \%$ of fly ash is applied as raw material for cement and concrete production. The remaining solid wastes are disposed in on-site ponds, nearby abandoned or active mine sites or landfills. Consequently, the ash piles increase continuously, and this uncontrolled waste disposal site may lead to radiological environmental contamination [3]. 
An alternative to reduce the environmental impact is recycling, transforming the coal combustion products into a value-added product. The coal ashes can be converted into zeolites due to their high contents of silicon and aluminum. Zeolites synthesized from coal ash are characterized by presenting adsorption properties, catalytic properties and high cation exchange capacity enabling at least 20 applications in various areas of activity. Zeolite synthesis is considered an advanced alternative, because this material is a high value product [5-7].

The classical alkaline conversion of coal ash produces zeolitic material containing mixtures of zeolitic phases and a significant amount of ash of unconverted coal (20-65\%) [5-7]. Thus, it is important to determine the radionuclides that remain in the ash content for further application of zeolite.

As the coal used at Figueira coal-fired power plant presents high uranium concentration when compared with other coals in Brazil $[1,3]$, the continuous monitoring is necessary to evaluate the environmental impact of the installation due to potential disturbance of radioactive equilibrium within the uranium series.

In the context of environmental pollution related to coal industry, additional sources of radionuclides are: tailing piles containing CCRs, effluents from coal mining; natural radionuclides emitted to the atmosphere.

The potential human exposure scenarios to TENORM are: atmospheric releases from stacks and ash piles, workers at coal-fired power plants and landfill sites, workers who manufacture and use building materials containing ash and population living around the plants [8].

The exposure to these radionuclides, in the form of CCRs and leaching products, has severe health impacts including bone damage, kidney damage and cancers [9].

The aim of the present study was to determine the radionuclide concentrations in coal, bottom ash, fly ash from cyclone and baghouse filters, zeolites synthesized from the ashes and two different soil samples collected in the vicinity of the power station. Additionally, the radiological health index radium equivalent $\left(\mathrm{Ra}_{\mathrm{eq}}\right)$, absorbed dose rate (D), annual gonadal dose equivalent (AGDE), annual effective dose equivalent (AEDE) and excess life time cancer risk (ELCR) were calculated to evaluate the potential hazard due to radiation exposition to these materials. 


\section{MATERIALS AND METHODS}

\subsection{Materials}

All the reagents used for experimental studies were of analytical grade. The samples of coal, fly ash from baghouse filter (FB), fly ash from cyclone filter (FC) and bottom ash (BA) were collected at the Figueira coal-fired power plant located in the Figueira County, in the north of Paraná State, Brazil (Figure 1A), following ABNT NBR 10007/87 [10]. Two deformed soil samples were collected at a distance of $500 \mathrm{~m}$ from the coal-fired power plant in a counter-wind direction. Soil sample 1 (Soil-1) was in the center of a pasture area and Soil sample 2 (Soil-2) was near the Laranjinha River. The location of the study area can be seen in Figure 1B. The samples (10 Kg) were collected at $30 \mathrm{~cm}$ depth, dried at room temperature for 2 weeks and stored in plastic bags for further analysis [11].
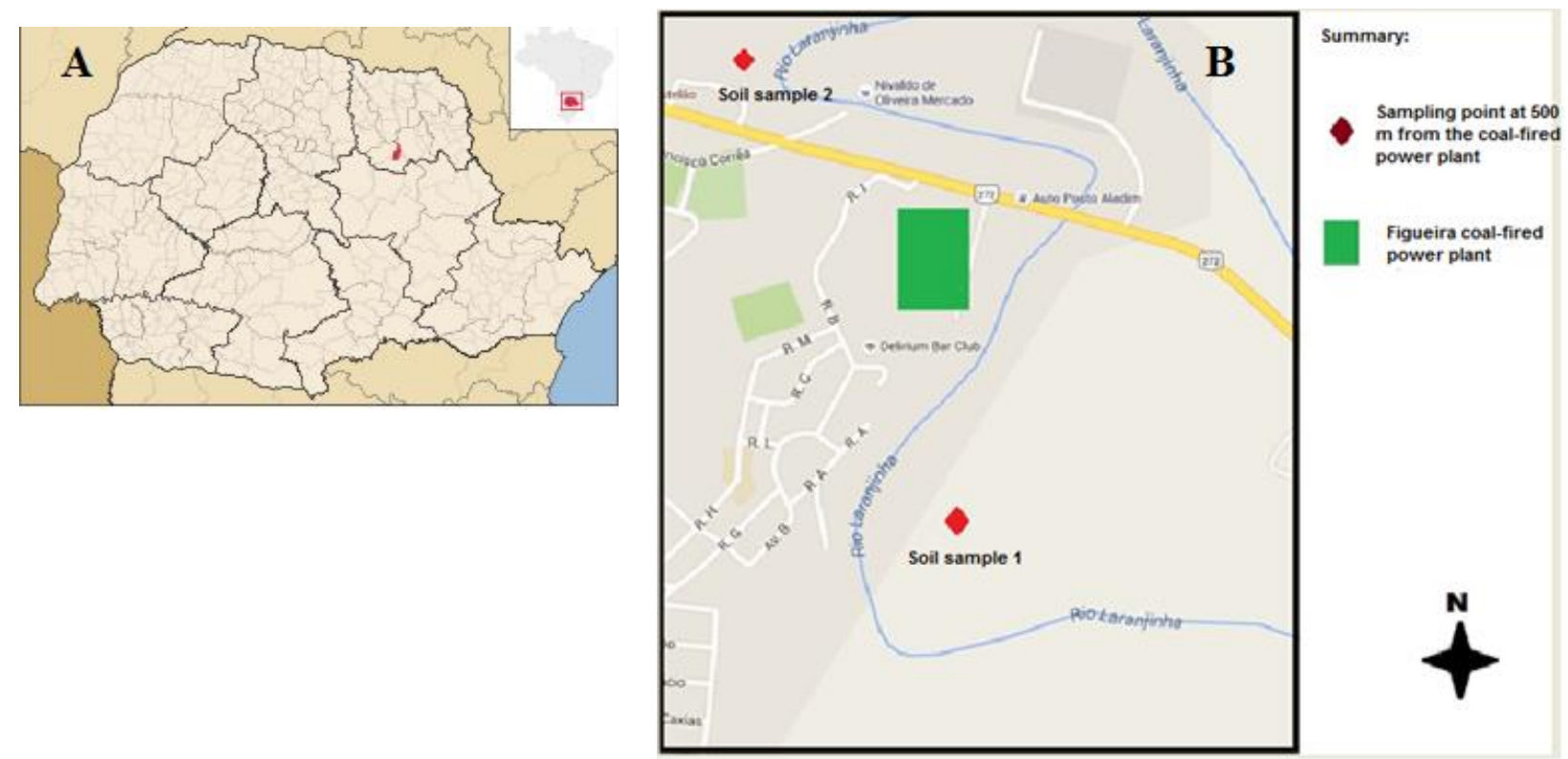

Fig. 1. Location of: (A) Figueira county; (B) Figueira Coal-fired Power Plant and collection sites for soil samples. 


\subsection{Synthesis of Zeolites from Coal Ashes}

The zeolite was prepared by hydrothermal activation of $20 \mathrm{~g}$ of coal ash at $100{ }^{\circ} \mathrm{C}$ in $160 \mathrm{ml}$ of $3.5 \mathrm{~mol} \mathrm{l}^{-1} \mathrm{NaOH}$ solution for $24 \mathrm{~h}$. The zeolitic material was repeatedly washed with deionized water to remove excess sodium hydroxide until the washing water had $\mathrm{pH} \sim 10$, then it was dried at $80{ }^{\circ} \mathrm{C}$ for $12 \mathrm{~h}$.

\subsection{Neutron Activation Analysis}

Neutron activation analysis was used to determine the concentrations of the elements $U$ and Th. For this determination, approximately $100 \mathrm{mg}$ of the sample were weighted and packed in polyethylene bags and irradiated in the IEA-R1 nuclear research reactor, at IPEN, in a neutron flux of $10^{12} \mathrm{n} \mathrm{cm}^{-2} \mathrm{~s}^{-1}$ for a period of 8 hours. Reference materials USGS STM-2, NIST SRM 1646a and a paper filter pipetted with a standard solution of the interest elements were also prepared and irradiated together with the samples to calculate the concentrations by the comparative method.

After the irradiation, two sets of measurement were done. The first, after a one-week period of cooling, to determine $U$ concentrations and, the second, after two weeks, to determine Th concentration. Samples were counted for a period of $5000 \mathrm{~s}$, in the first and second measurements, by using an EG\&G Ortec Ge high pure Gamma Spectrometer detector (AMETEK Inc., USA) and associated electronics, with a resolution of 0.88 and $1.90 \mathrm{keV}$ for ${ }^{57} \mathrm{Co}(122 \mathrm{keV})$ and ${ }^{60} \mathrm{Co}(1332 \mathrm{keV})$, respectively [12].

Activity concentrations of ${ }^{238} \mathrm{U}$ and ${ }^{232} \mathrm{Th}$ were obtained by their specific activity using the conversion factor of 12.5 and 4.05 , respectively.

\subsection{Gamma Spectrometry}

The concentration of the natural radionuclides ${ }^{226} \mathrm{Ra},{ }^{228} \mathrm{Ra},{ }^{210} \mathrm{~Pb}$ and ${ }^{40} \mathrm{~K}$ was carried out by nondestructive $\gamma$-ray spectrometry. Samples were packed in $50 \mathrm{~cm}^{3}$ polypropylene cylindrical containers and they were kept sealed for at least 30 days in order to reach radioactive equilibrium between ${ }^{226} \mathrm{Ra}$ and ${ }^{222} \mathrm{Rn}$ progenies. 
A HPGe EG\&G Ortec detector with $60 \%$ of relative efficiency and $2.09 \mathrm{keV}$ resolution at 1.33 $\mathrm{MeV}$ and associated electronic devices were used, with live counting time of 160,000 s. The spectra were acquired by a multichannel analyzer and, for the analysis, MAESTRO II software package was used. The activity concentration for ${ }^{210} \mathrm{~Pb}$ in the samples was corrected for self-absorption according to the method described in [13]. The detector efficiency was calibrated by using the reference material IAEA-RGU-1, IAEA-RGTh-1 and IAEA-RGK-1.

\section{RESULTS AND DISCUSSION}

\subsection{Activity Concentrations in Coal and its Combustion Residues}

The results obtained for the activity concentration of ${ }^{238} \mathrm{U},{ }^{226} \mathrm{Ra},{ }^{210} \mathrm{~Pb},{ }^{228} \mathrm{Ra},{ }^{232} \mathrm{Th}$ and ${ }^{40} \mathrm{~K}$ in the pulverized coal, bottom ash and fly ashes are listed in Table 1. According to UNSCEAR [14], the mean natural radionuclide concentration in coal is $35 \mathrm{~Bq} \mathrm{~kg}^{-1}$ for ${ }^{238} \mathrm{U}$ (range: 16-110), $35 \mathrm{~Bq} \mathrm{~kg}^{-1}$ (range:17-60) for ${ }^{226} \mathrm{Ra}, 30 \mathrm{~Bq} \mathrm{~kg}{ }^{-1}$ (range:1-64) for ${ }^{232} \mathrm{Th}$, and $400 \mathrm{~Bq} \mathrm{~kg}$ (range:140-850) for ${ }^{40} \mathrm{~K}$.

As one sees from Table 1, the ${ }^{232} \mathrm{Th}$ and ${ }^{40} \mathrm{~K}$ concentrations are in the range of coal reported, and the obtained values for ${ }^{238} \mathrm{U}$ and ${ }^{226} \mathrm{Ra}$ are higher than the UNSCEAR values in coal [14].

The ashes fraction presented concentrations ranging from 683.5 to $1479 \mathrm{~Bq} \mathrm{~kg}^{-1}$ for ${ }^{238} \mathrm{U}$, from 484 to $1086 \mathrm{~Bq} \mathrm{~kg}^{-1}$ for ${ }^{226} \mathrm{Ra}$, from 291 to $1891 \mathrm{~Bq} \mathrm{~kg}^{-1}$ for ${ }^{210} \mathrm{~Pb}$, from 67 to $111 \mathrm{~Bq} \mathrm{~kg}^{-1}$ for ${ }^{228} \mathrm{Ra}$, from 80 to $87 \mathrm{~Bq} \mathrm{~kg}^{-1}$ for ${ }^{232} \mathrm{Th}$ and from 489 to $718 \mathrm{~Bq} \mathrm{~kg}^{-1}$ for ${ }^{40} \mathrm{~K}$.

According to standard values published by UNSCEAR [14], the world average concentrations in fly ashes are $240 \mathrm{~Bq} \mathrm{~kg}{ }^{-1}$ for ${ }^{226} \mathrm{Ra}, 70 \mathrm{~Bq} \mathrm{~kg}{ }^{-1}$ for ${ }^{232} \mathrm{Th}, 265 \mathrm{~Bq} \mathrm{~kg}^{-1}$ for ${ }^{40} \mathrm{~K}_{\text {and }} 200 \mathrm{~Bq} \mathrm{~kg}^{-1}$ for ${ }^{238} \mathrm{U}_{\text {. }}$ Comparing the present results, the fly ashes presented higher activity concentration than standard values for all the radionuclides, except for ${ }^{232} \mathrm{Th}$.

It can be seen that all radionuclide concentrations increase from the coal to ash and the highest concentrations were observed in the fly ash from baghouse filter, which has the finest particles [3]. In general, the radionuclide concentrations decreased in the following order FB $>$ FC $>$ BA $>$ coal. The variation of the activity concentration values is due to the differences physical, chemical and geo-chemical properties of materials. 
Previous studies have shown that according to the Brazilian Guideline CNEN-NN 4.01 [15], the Figueira power plant was classified in Category III due to the levels of radioactivity in the ash samples which presented estimated values of 8,776 and $10,700 \mathrm{~Bq} \mathrm{Kg}^{-1}$ [3]. The concentration of the uranium series of ashes found in this study was lower than those values previously observed and was therefore, under the limit adopted by the Brazilian Guideline for Category III.

Table 1: Activity concentrations of coal, fly ash from baghouse filter (FB), fly ash from cyclone filter (FC) and bottom ash (BA) (in $\mathrm{Bq} \mathrm{kg}^{-1}$ )

\begin{tabular}{lcccc}
\hline & Coal & BA & FC & FB \\
\hline${ }^{238} \mathrm{U}$ & $216 \pm 38$ & $683.5 \pm 76$ & $867.5 \pm 143$ & $1479 \pm 305$ \\
${ }^{226} \mathrm{Ra}$ & $180 \pm 32$ & $484 \pm 84$ & $661 \pm 115$ & $1086 \pm 189$ \\
${ }^{210} \mathrm{~Pb}$ & $<155$ & $291 \pm 171$ & $806 \pm 300$ & $1891 \pm 514$ \\
${ }^{228} \mathrm{Ra}$ & $27 \pm 7$ & $77 \pm 24$ & $67 \pm 21$ & $111 \pm 34$ \\
${ }^{232} \mathrm{Th}$ & $28 \pm 2$ & $83 \pm 5$ & $80 \pm 5$ & $87 \pm 5$ \\
${ }^{40} \mathrm{~K}$ & $192 \pm 13$ & $597 \pm 39$ & $489 \pm 33$ & $718 \pm 47$ \\
\hline
\end{tabular}

The enrichment factor $(\mathrm{EF})$ is defined as the ratio of the content of a radionuclide $(\mathrm{X})$ and ${ }^{40} \mathrm{~K}$ in the sample divided by the corresponding ratio in the coal. This normalizes the apparent enrichment resulting from the loss of carbon or organic matter during the firing processes. ${ }^{40} \mathrm{~K}$ is used in the formula since the concentration of ${ }^{40} \mathrm{~K}$ remained more or less constant in all samples [16].

Table 2 presents the EF value for the different ash samples. In most of the cases the enrichment levels were about 0.8-1.8 times higher in the ashes than in feed coal. The fly ash from baghouse filter was the most enriched for all the radionuclides, except for Th. 
Table 2: Enrichment factor of fly ash from baghouse filter (FB), fly ash from cyclone filter (FC) and bottom ash (BA)

\begin{tabular}{lllll}
\hline & \multicolumn{2}{c}{ EF } \\
& ${ }^{\mathbf{2 3 8}} \mathbf{U}$ & ${ }^{\mathbf{2 2 6}} \mathbf{R a}$ & ${ }^{{ }^{228} \mathbf{R a}}$ & ${ }^{\mathbf{2 3 2}} \mathbf{T h}$ \\
\hline BA & 1.02 & 0.865 & 0.917 & 0.953 \\
FC & 1.58 & 1.44 & 0.974 & 1.12 \\
FB & 1.83 & 1.61 & 1.01 & 0.831 \\
\hline
\end{tabular}

\subsection{Activity Concentrations in Soil Samples}

The combustion of coal results in the release of natural radioactive elements into the environment and in the redistribution of these radioactive elements in the surface soil particularly in the vicinity of coal-fired power plants. The Figueira coal-fired power plant has been operating for more than 35 years, and only in 1998, a filter system for collecting fly ashes (cyclone and filtering bag-coupled filter system) was installed.

Radionuclide $\left({ }^{238} \mathrm{U},{ }^{226} \mathrm{Ra},{ }^{210} \mathrm{~Pb},{ }^{228} \mathrm{Ra},{ }^{232} \mathrm{Th}\right.$ and $\left.{ }^{40} \mathrm{~K}\right)$ concentrations obtained in the two soil sampling points are presented in Table 3. The soil samples were collected at about $500 \mathrm{~m}$ distant from the coal-fired power plant and showed activity concentrations in the range of 28 and $70 \mathrm{~Bq} \mathrm{~kg}^{-}$ 1, 23 and $50 \mathrm{~Bq} \mathrm{~kg}^{-1}, 199$ and $271 \mathrm{~Bq} \mathrm{~kg}^{-1}, 22$ and $43 \mathrm{~Bq} \mathrm{~kg}^{-1}, 23$ and $48 \mathrm{~Bq} \mathrm{~kg}^{-1}, 237$ and $258 \mathrm{~Bq}$ $\mathrm{kg}^{-1}$ for ${ }^{238} \mathrm{U},{ }^{226} \mathrm{Ra},{ }^{210} \mathrm{~Pb},{ }^{228} \mathrm{Ra},{ }^{232} \mathrm{Th}$ and ${ }^{40} \mathrm{~K}$, respectively.

According to UNSCEAR [14], the current worldwide average values for soil concentrations are 32 $\mathrm{Bq} \mathrm{kg}{ }^{-1}$ for ${ }^{226} \mathrm{Ra}, 45 \mathrm{~Bq} \mathrm{~kg}^{-1}$ for ${ }^{232} \mathrm{Th}, 420 \mathrm{~Bq} \mathrm{~kg}{ }^{-1}$ for ${ }^{40} \mathrm{~K}$ and $33 \mathrm{~Bq} \mathrm{~kg}{ }^{-1}$ for ${ }^{238} \mathrm{U}$. Therefore, the activity concentration of ${ }^{238} \mathrm{U}$ is higher than worldwide average concentration for soil samples from Figueira region. 
Table 3: Natural radionuclide content in soil samples (in $\mathrm{Bq} \mathrm{kg}{ }^{-1}$ )

\begin{tabular}{lcc}
\hline & Soil-1 & Soil-2 \\
\hline${ }^{238} \mathrm{U}$ & $70 \pm 12$ & $28 \pm 8$ \\
${ }^{226} \mathrm{Ra}$ & $50 \pm 9$ & $23 \pm 4$ \\
${ }^{210} \mathrm{~Pb}$ & $199 \pm 101$ & $271 \pm 128$ \\
${ }^{228} \mathrm{Ra}$ & $43 \pm 13$ & $22 \pm 5$ \\
${ }^{232} \mathrm{Th}$ & $48 \pm 3$ & $23 \pm 1$ \\
${ }^{40} \mathrm{~K}$ & $237 \pm 15$ & $258 \pm 17$ \\
\hline
\end{tabular}

In general, the radionuclide concentrations of Soil-1 sample were higher than the Soil-2 sample. This fact is probably due to the sampling locations in addition to the soil properties that can influence the adsorption of radionuclides. Soil-2 presents a higher moisture value due to its proximity to the Laranjinha River. The clay fraction and sand fraction were predominant in Soil-1 and Soil-2, respectively. Lower concentrations were observed for ${ }^{232} \mathrm{Th}$ and ${ }^{228} \mathrm{Ra}$ which were also found in low concentrations in coal and ashes samples.

The obtained concentrations of naturally occurring radionuclides were close to the mean values of the other study with soil samples collect in Figueira coal-fired power plant, with exception of ${ }^{210} \mathrm{~Pb}$ that presented higher values in this work [17]. ${ }^{210} \mathrm{~Pb}$ is one of the most volatile radionuclides and tends to be enriched on the finer particles, being transported to the soil adsorbed in the fly ash or precipitate with dust particles. Moreover, most ${ }^{222} \mathrm{Rn}$ that migrates into or out of the coal seam decays to ${ }^{210} \mathrm{~Pb}$ because their half time is short (3.8 days).

\subsection{Activity Concentrations in Zeolites Samples}

Coal ash, as for all materials of mineral origin, is a source of natural radioactivity. Recycling coal fly ash can be a good alternative to disposal and could achieve significant economic and environmental benefits as well. Hence, it's important to investigate the radiation impact of coal ashes reutilization, mainly about fly ash.

Table 4 presents the values obtained of radioactivity concentrations in zeolites synthesized from: bottom ash (ZBA), fly ash from cyclone filter (ZFC) and fly ash from baghouse filter (ZFB). The results showed that the activity concentrations of the radionuclides presented similar values to 
respective coal ashes used as raw material for zeolite synthesis (except for ${ }^{210} \mathrm{~Pb}$ and ${ }^{40} \mathrm{~K}$ ), as can be seen in Table 1.

Table 4: Natural radionuclide content in zeolite from bottom ash (ZBA), zeolite from fly ash from cyclone filter (ZFC) and zeolite from fly ash from baghouse filter (ZFB) (in $\mathrm{Bq} \mathrm{kg}^{-1}$ )

\begin{tabular}{cccc}
\hline & ZBA & ZFC & ZFB \\
\hline${ }^{238} \mathrm{U}$ & $698 \pm 77$ & $849 \pm 139$ & $1266 \pm 142$ \\
${ }^{226} \mathrm{Ra}$ & $360 \pm 64$ & $370 \pm 65$ & $698 \pm 124$ \\
${ }^{210} \mathrm{~Pb}$ & $1718 \pm 890$ & $3352 \pm 1423$ & $2446 \pm 1234$ \\
${ }^{228} \mathrm{Ra}$ & $81 \pm 22$ & $87 \pm 27$ & $113 \pm 28$ \\
${ }^{232} \mathrm{Th}$ & $85 \pm 5$ & $83 \pm 5$ & $108 \pm 6$ \\
${ }^{40} \mathrm{~K}$ & $<43$ & $344 \pm 23$ & $180 \pm 12$
\end{tabular}

\subsection{Comparison of Radioactivity Concentrations of Samples}

The radionuclide concentrations $\left({ }^{238} \mathrm{U},{ }^{226} \mathrm{Ra},{ }^{210} \mathrm{~Pb},{ }^{228} \mathrm{Ra},{ }^{232} \mathrm{Th}\right.$ and $\left.{ }^{40} \mathrm{~K}\right)$ obtained in samples collected at the Figueira coal-fired power plant in this work were compared with the results from other studies. Results are summarized in Tables 5-7.

Table 5 shows that the activity concentrations in coal were lower that samples collected about 10 years ago [3], except for ${ }^{232} \mathrm{Th}$, whose concentration was within the observed range. The concentration of ${ }^{238} \mathrm{U}$ presented a very close value with to one of the samples collected by Galhardi et al. in 2017 [18].

A similar result to coal was observed with ashes samples (Table 6). In this case, besides the ${ }^{232} \mathrm{Th}$, the activity concentration of ${ }^{40} \mathrm{~K}$ also was within the range reported in previous study [3].

When compared with values obtained from other samples, the highest activity concentration for ${ }^{210} \mathrm{~Pb}$ in soil was obtained in the present study (Table 7). The activity levels of ${ }^{238} \mathrm{U},{ }^{226} \mathrm{Ra},{ }^{228} \mathrm{Ra}$, ${ }^{232} \mathrm{Th}$ and ${ }^{40} \mathrm{~K}$ were within the mean of values reported by other studies on the radioactive contents in soil samples. It should be noted that the samples were collected in different locations. 
Table 5: Comparison of activity concentration of radionuclides $\left(\mathrm{Bq} \mathrm{kg}^{-1}\right)$ with published results in

\begin{tabular}{cccc} 
& & coal & Ref. [18] $^{\mathbf{2}}$ \\
\hline${ }^{238} \mathrm{U}$ & $216 \pm 38$ & Ref. [3] $]^{\mathbf{1}}$ & Sample C1 822 \pm 24 \\
${ }^{226} \mathrm{Ra}$ & $180 \pm 32$ & Average 1078 \pm 195 & \\
${ }^{210} \mathrm{~Pb}$ & $<155$ & Average $1001 \pm 200$ & \\
${ }^{228} \mathrm{Ra}$ & $27 \pm 7$ & - & \\
${ }^{232} \mathrm{Th}$ & $28 \pm 2$ & Average $30 \pm 8$ & \\
${ }^{40} \mathrm{~K}$ & $192 \pm 13$ & Average $310 \pm 104$ & \\
\hline
\end{tabular}

(1) average \pm standard deviation and range of samples collected for one year; (2) two different samples 
Table 6: Comparison of activity concentration of radionuclides $\left(\mathrm{Bq} \mathrm{kg}^{-1}\right)$ with published results in coal ashes: fly ash from baghouse filter (FB), fly ash from cyclone filter (FC) and bottom ash (BA)

\begin{tabular}{|c|c|c|c|c|c|c|c|}
\hline & \multicolumn{3}{|c|}{ Present Study } & \multicolumn{3}{|c|}{ Ref. $[3]^{1}$} & \multirow[t]{2}{*}{ Ref. $[18]^{2}$} \\
\hline & $\mathbf{B A}$ & FC & FB & BA & FC & FB & \\
\hline${ }^{238} \mathrm{U}$ & $\begin{array}{c}683.5 \pm \\
76\end{array}$ & $\begin{array}{c}867.5 \pm \\
143\end{array}$ & $\begin{array}{c}1479 \pm \\
305\end{array}$ & $\begin{array}{c}\text { Average } \\
1945 \pm \\
290 \\
\text { Range } \\
1635-2352\end{array}$ & $\begin{array}{c}\text { Average } \\
1858 \pm \\
326 \\
\text { Range } \\
1995-5198\end{array}$ & $\begin{array}{c}\text { Average } \\
3097 \pm 919 \\
\text { Range } \\
1995-5198\end{array}$ & $\begin{array}{l}\text { Sample A1 } \\
1167 \pm 27 \\
\text { Sample A2 } \\
651 \pm 20\end{array}$ \\
\hline${ }^{226} \mathrm{Ra}$ & $484 \pm 84$ & $661 \pm 115$ & $\begin{array}{c}1086 \pm \\
189\end{array}$ & $\begin{array}{c}\text { Average } \\
2411 \pm \\
851 \\
\text { Range } \\
1387-3621 \\
\end{array}$ & $\begin{array}{c}\text { Average } \\
1909 \pm \\
441 \\
\text { Range } \\
1442-2718 \\
\end{array}$ & $\begin{array}{c}\text { Average } \\
3024 \pm 924 \\
\text { Range } \\
1875-3773\end{array}$ & \\
\hline${ }^{210} \mathrm{~Pb}$ & $\begin{array}{c}291 \pm \\
171\end{array}$ & $806 \pm 300$ & $\begin{array}{c}1891 \pm \\
514\end{array}$ & $\begin{array}{c}\text { Average } \\
2644 \pm \\
724 \\
\text { Range } \\
1649-3463\end{array}$ & $\begin{array}{c}\text { Average } \\
4665 \pm \\
1060 \\
\text { Range } \\
3292-6154\end{array}$ & $\begin{array}{c}\text { Average } \\
10379 \pm \\
3556 \\
\text { Range } \\
6353-14641\end{array}$ & \\
\hline${ }^{228} \mathrm{Ra}$ & $77 \pm 24$ & $67 \pm 21$ & $111 \pm 34$ & - & - & - & \\
\hline${ }^{232} \mathrm{Th}$ & $83 \pm 5$ & $80 \pm 5$ & $87 \pm 5$ & $\begin{array}{c}\text { Average } \\
62 \pm 20 \\
\text { Range } \\
45-92\end{array}$ & $\begin{array}{c}\text { Average } \\
58 \pm 12 \\
\text { Range } \\
43-95\end{array}$ & $\begin{array}{c}\text { Average } \\
73 \pm 12 \\
\text { Range } \\
65-124\end{array}$ & \\
\hline${ }^{40} \mathrm{~K}$ & $597 \pm 39$ & $489 \pm 33$ & $718 \pm 47$ & $\begin{array}{c}\text { Average } \\
486 \pm 42 \\
\text { Range } \\
422-525\end{array}$ & $\begin{array}{c}\text { Average } \\
650 \pm 181 \\
\text { Range } \\
471-1144\end{array}$ & $\begin{array}{c}\text { Average } \\
621 \pm 33 \\
\text { Range } \\
577-968\end{array}$ & \\
\hline
\end{tabular}

(1) average \pm standard deviation and range of samples collected during one year; (2) two different samples 
Table 7: Comparison of activity concentration of radionuclides $\left(\mathrm{Bq} \mathrm{kg}^{-1}\right)$ with published results in soil

\begin{tabular}{lccccc}
\hline & \multicolumn{2}{c}{ Present Study } & \multicolumn{2}{c}{ Ref. [17] $^{\mathbf{1}}$} & ${\text { Ref. }[18]^{\mathbf{2}}}$ \\
\hline Soil-1 & Soil-2 & Sample 1 & Sample 2 & \\
\hline${ }^{\mathbf{2 3 8}} \mathbf{U}$ & $70 \pm 12$ & $28 \pm 8$ & - & - & Sample S1 22.8 \pm 1.3 \\
${ }^{\mathbf{2 2 6}} \mathbf{R a}$ & $50 \pm 9$ & $23 \pm 4$ & $50 \pm 22$ & $133 \pm 59$ & \\
${ }^{\mathbf{2 1 0}} \mathbf{P b}$ & $199 \pm 101$ & $271 \pm 128$ & $80 \pm 27$ & $182 \pm 50$ & \\
${ }^{{ }^{228}} \mathbf{R a}$ & $43 \pm 13$ & $22 \pm 5$ & - & - & \\
${ }^{{ }^{232}} \mathbf{T h}$ & $48 \pm 3$ & $23 \pm 1$ & $31 \pm 10$ & $39 \pm 9$ & \\
${ }^{\mathbf{4 0}} \mathbf{K}$ & $237 \pm 15$ & $258 \pm 17$ & $190 \pm 56$ & $233 \pm 96$ & \\
\hline
\end{tabular}

(1) Sample 1: Mean \pm standard deviation, soil sample collect at $1 \mathrm{Km}$ from Figueira coal -fired power plant, horizont A; Sample 2: Mean \pm standard deviation, soil sample collect in Notthwest $(<1 \mathrm{Km})$ transect from Figueira coal -fired power plant, horizont A; (2) samples collected in different locations

\subsection{Radiological Assessment}

The calculation of the radiological hazard index is one of the most common procedures to evaluate the risk for the population due to TENORM exposure; therefore, the radiological health index radium equivalent (Raeq), absorbed dose rate in the air (D), annual gonadal dose equivalent (AGDE), annual effective dose equivalent (AEDE) and excess life time cancer risk (ELCR) were calculated. The results are shown in Table 8 . 
Table 8: Radiological health index radium equivalent $\left(\mathrm{Ra}_{\mathrm{eq}}, \mathrm{Bq} \mathrm{kg}^{-1}\right)$, absorbed dose rate $\left(\mathrm{D}, \mathrm{nGy}^{-1}\right.$ ), annual gonadal dose equivalent (AGDE, $\mathrm{mSy}^{-1}$ ), annual effective dose equivalent $\left(\mathrm{AEDE}, \mathrm{mSv}^{-1}\right)$ and excess life time cancer risk (ELCR, admentional) determined for the coal ash, zeolites and soil samples.

\begin{tabular}{cccccc}
\hline & $\mathrm{Ra}_{\mathrm{eq}}$ & $\mathrm{D}$ & $\mathrm{AGDE}$ & $\mathrm{AEDE}$ & ELCR \\
\hline & $\mathrm{Bq} \mathrm{kg}^{-1}$ & $\mathrm{nGy} \mathrm{h}^{-1}$ & $\mathrm{mSy} \mathrm{y}^{-1}$ & $\mathrm{mSv} \mathrm{y}^{-1}$ & ${\mathrm{x} 10^{-3}}^{-1}$ \\
\hline Coal & 235 & 108 & 0.86 & 0.53 & 1.85 \\
$\mathrm{BA}$ & 648 & 298 & 2.68 & 1.46 & 5.12 \\
FC & 813 & 374 & 3.21 & 1.83 & 6.42 \\
FB & 1265 & 584 & 5.23 & 2.86 & 10.03 \\
ZBA & 482 & 218 & 2.55 & 1.07 & 3.74 \\
ZFC & 516 & 236 & 3.12 & 1.16 & 4.05 \\
ZFB & 866 & 395 & 4.49 & 1.94 & 6.78 \\
Soil-1 & 137 & 62 & 0.50 & 0.30 & 1.06 \\
Soil-2 & 75 & 35 & 0.27 & 0.17 & 0.60 \\
\hline
\end{tabular}

The Radium equivalent activity $\left(\mathrm{Ra}_{\mathrm{eq}}\right)$ is a measurement of the radiation exposure considering the activity of materials with different content of primordial radionuclides which also considers external and internal effective dose from radon and its decay progeny.

It assumes that specific activity of $370 \mathrm{~Bq} \mathrm{~kg}^{-1}$ for ${ }^{226} \mathrm{Ra}$ uniformly distributed in any environmental sample can result in annual effective dose of $1 \mathrm{mSv}$ at $1 \mathrm{~m}$ above ground level [19]. This index is mainly used to evaluate the application of a material for construction purpose.

The results showed that both coal ashes and zeolites present $\mathrm{Ra}_{\mathrm{eq}}$ values higher than $370 \mathrm{Bk} \mathrm{kg}^{-1}$, indicating that the coal ash is not suitable for use as construction material, nevertheless its uses as adsorbent would not pose a threat to health due to the exposure time and the small portion handled. According to UNSCEAR [14], the world average value of absorbed dose rate (D) in air is $58 \mathrm{nGy} \mathrm{h}^{-1}$. Results showed higher values even the soil-1 sample indicating possible influence of the coal ash from power plant in this sampling point.

The annual gonadal dose equivalent (AGDE) measures the genetic significance of the dose equivalent received by the population's reproductive organs, bone marrow and bone surface cells per year [20]. The annual effective dose equivalent (AEDE) also considers the adsorbed dose rate as 
a function of the time exposure to the radioactive source, with an occupancy factor of 0.2 for outdoor exposure [21]. Excess life time cancer risk (ELCR) is related to the risk of fatal cancer during a life time of 70 years [22]. It is possible to observe that the conversion of coal ash in zeolites generally results in a small decrease of these radiological indices and it is also worth noting that the technological use of these materials implies in its removal from the environment decreasing the public exposition and environmental contamination.

\section{CONCLUSION}

The power plant located in the Figueira County has been working since 1963, but only in 1998 the cyclone and bag filters were installed in the plant. The coal from Figueira presents high uranium concentration when compared with other coals in Brazil. Thus, the rate of radioactive elements released into environment must be monitored regularly because human exposure of to radionuclides induces severe symptoms in vital body organs, particularly the lungs, kidney and bones.

The activity concentrations for the uranium series in coal, coal combustion residuals (fly ash from baghouse filter, fly ash from cyclone filter and bottom ash) and soil samples, collected in the vicinity of the Figueira power plant were determined and the results were compared with previous studies.

Radioactive evaluation of all samples showed concentrations above the world average mainly for

${ }^{238} \mathrm{U}$. The radioactive elements were enriched in ashes and the concentration in fly ash was found to be higher than the one in other ashes. The ${ }^{210} \mathrm{~Pb}$ reached the highest values for soil samples when compared to value found in previous study.

The concentration of natural radionuclides presented no significant change when coal ashes were used as starting material for zeolite synthesis.

The results indicated that the thermal power plant operation presents considerable risks in the investigated area due to the high ash content of coal. The radiological hazard indices indicated that the material is not suitable for use as construction material and its disposition in the environment may pose a threat to the surrounding population.

In order to reduce the contamination of workers and population where coal-fired thermal power plant is situated, the following recommendations are suggested: to reduce the ash contents of coal 
by the benefaction process; utilization of coal ashes as alternative source of radioactive elements, mainly uranium and maintain a temporal evaluation of the activity concentrations.

\section{ACKNOWLEDGMENT}

The authors are grateful to Figueira coal-fired power plant for providing all samples for this study.

\section{REFERENCES}

1. FLUES, M.; CAMARGO, I. M. C.; FIGUEIREDO FILHO, P. M.; SILVA, P. S. C.; MAZZILLI, B. P. Evaluation of radionuclides concentration in Brazilian coals. Fuel, v. 86, p. 807-812, 2007.

2. BECK, H. I. Radiation exposure due to fossil fuel combustion. Radiation Physics and Chemistry, v. 34, p. 285-93, 1989.

3. FLUES, M.; CAMARGO, I. M. C.; SILVA, P. S. C.; MAZZILLI, B. P. Radioactivity of coal and ashes from Figueira coal power plant in Brazil. Journal of Radioanalytical and Nuclear Chemistry, v. 270, p. 597-602, 2006.

4. FUNGARO, D. A.; IZIDORO, J. C.; SANTOS, F. S.; WANG, S. Coal Fly Ash from Brazilian Power Plants: Chemical and Physical Properties and Leaching Characteristics. In: SARKER, P. K. Fly Ash: Chemical Composition, Sources and Potential Environmental Impacts. Hauppauge, N.Y.: Nova Science Publishers. Chapter 5, 2013, p. 145-164.

5. IZIDORO, J. C.; FUNGARO, D. A.; SANTOS, F. S.; WANG, S. Characteristics of Brazilian coal fly ashes and their synthesized zeolites. Fuel Processing Technology, v. 97, p.38-44, 2012.

6. IZIDORO, J. C.; FUNGARO, D. A.; WANG, S. Zeolite synthesis from Brazilian coal fly ash for removal of $\mathrm{Zn}^{2+}$ and $\mathrm{Cd}^{2+}$ from water. Advanced Materials Research, v. 356-360, p. 19001908, 2012.

7. FUnGARO, D. A. Synthesis of Value-added Materials from Coal Combustion Products and Biomass Ash. American Association for Science and Technology Communications, 2014. Available at <http://www.aascit.org>. Last accessed: 13 Sep. 2018. 
8. PARAMI, V. K. Determination of technologically enhanced naturally occurring radioactive material (TENORM) in ashes from coal-fired thermal power plants in the Philippines. Thesis, University of the Philippines, Diliman, Quezon City (Philippines), 2008.

9. GAGNAIRE, B.; ADAM-GUILLERMIN, C.; BOURON, A.; LESTAEVEL, P. (2011) The effects of radionuclides on animal behavior. Reviews of Environmental Contamination and Toxicology, v. 210, p. 35-58, 2011.

10. ABNT NBR 10007; Associação Brasileira de Normas Técnicas. Amostragem de resíduos: procedimento. Rio de Janeiro, 1987.

11. EMBRAPA. Centro Nacional de Pesquisa de Solos. Manual de métodos de análise de solo, 2nded. EMBRAPA-CNPS, Rio de Janeiro, 1997.

12. IAEA - International Atomic Energy Agency. Practical aspects of operating a neutron analysis laboratory. IAEA -TECDOC- 564, Vienna: IAEA, 1999. 252p.

13. CUTSHALL, N. H.; LARSER, I. L.; OLSEN, C. R. Direct analysis of $210 \mathrm{~Pb}$ in sediment samples: self-absorption corrections. Nuclear Instruments and methods, v. 206, p. 309-312, 1983.

14. UNSCEAR - United Nations Scientific Committee on the Effects of Atomic Radiation. Sources and effects of ionizing radiation. UNSCEAR Report 2000, Volume I- ANNEX B, 2010.

15. CNEN - Comissão Nacional de Energia Nuclear. CNEN-NN 4.01 - Requisitos de Segurança e Proteção Radiológica para Instalações Mínero-industriais, published in Diário Oficial da União (DOU), Jan. 2005.

16. COLES, D.G., RAGAINL, R.C., ONDOV, J.M., 1978. Behavior of natural radionuclides in Western coal-fired power plants. Environmental Science \& Technology, v.12, p.442-446, 1978.

17. FLUES, M.; MORAES, V.; MAZZILLI, B. P. The influence of a coal-fired power plant operation on radionuclide concentrations in soil. Journal of Environmental Radioactivity, v. 63, p. 285-294, 2002.

18. GALHARDI J.A, GARCÍA-TENORIO R., BONOTTO DM, DÍAZ FRANCÉS I, Motta J. G. Natural radionuclides in plants, soils and sediments affected by U-rich coal mining activities in Brazil. Journal of Environmental Radioactivity, v.177 p. 37-47, 2017. 
19. BERETKA, J., MATTHEW, P. J. Natural radioactivity of Australian building materials, industrial waste sand by-products. Health Phys. v. 48, p. 87-95, 1985.

20. UNSCEAR. Effects and risks of ionizing radiation. United Nations, New York, 1988. p 565571.

21. SINGH, J, SINGH, H, SINGH, S, BAJWA, BS, SONKAWADE, RG Comparative study of natural radioactivity levels in soil samples from the Upper Siwaliks and Punjab, India using gamma-ray spectrometry. J Environ Radioact. v. 100, p. 94-98, 2009.

22. TASKIN, H., KARAVUS, M., AY, P., TOPUZOGLU, A., HINDIROGLU, S., KARAHAN, G. Radionuclide concentrations in soil and life time cancer risk due to the gamma radioactivity in Kirklareli, Turkey. J Environ Radioact. v. 100, p. 49-53, 2009. 